\title{
PENENTUAN NILAI KALOR BRIKET DENGAN MEMVARIASIKAN BERBAGAI BAHAN BAKU
}

\author{
Samsinar, Asri Saleh, dan Waode Rustiah \\ Jurusan Kimia, Fakultas Sains dan Teknologi, UIN Alauddin Makassar \\ Email: syamsinar_76@yahoo.com
}

\begin{abstract}
Limitations of the availability of non -renewable energy sources. Cocoa shell waste and sawdust widespread everywhere and can be used as an alternative energy source that is to cultivate and make fuel, one of which briquetting. The composition of the material that is $(90: 1075: 25$ and $50: 50)$. After mixing the briquettes are printed using a printer briquettes. From this study, the best calorific value contained in the ratio of sawdust 90 : Water Hyacinth 10 is $6223.20 \mathrm{cal} / \mathrm{g}$, the ratio of sawdust $90: 10$ cocoa skin is $5953.72 \mathrm{cal}$ / $\mathrm{g}$ and Leather Cocoa 90: Water Hyacinth 10 ie 6066, $09 \mathrm{cal} / \mathrm{g}$. The best density value in comparison sawdust : cocoa skin (75:25) ie $1.05 \mathrm{~kg} / \mathrm{cm} 3$. Best values compressive strength in comparison cocoa skin : water hyacinth (50:50) ie $2.32 \mathrm{~kg} / \mathrm{cm} 3$. Best water content ratio of sawdust : water hyacinth (90:10) ie $3.89 \%$ ash content .Value best comparison Leather cocoa : water hyacinth (90:10) is $0.66 \%$. Volatile matter best value comparison cocoa skin : water hyacinth $90: 10)$ ie $13.1 \%$.The best comparison value of fixed carbon sawdust : cocoa skin $(90: 10)$ is $62,34 \%$.
\end{abstract}

Keywords: bomb kalorimeter, briquette, calorific value, cocoashel, Hyacinth (Eicchornia crassipes).

\section{PENDAHULUAN}

Perkembangan ekonomi di era globalisasi menyebabkan pertambahan konsumsi energi di berbagai sektor kehidupan. Bukan hanya negara-negara maju, tapi hampir semua negara mengalami termasuk Indonesia, walaupun terkena dampak krisis ekonomi, tetap mengalami pertumbuhan konsumsi energi. Sementara itu cadangan energi nasional akan semakin menipis apabila tidak ditemukan cadangan energi baru. Oleh karena itu, perlu dilakukan berbagai terobosan untuk mencegah terjadinya krisis energi.

Tingkat konsumsi minyak naik pertahunnya. Pada tahun berikutnya diperkirakan akan terus menerus meningkat, sehingga persediaan minyak di Indonesia akan semakin menipis. Dengan adanya kondisi seperti ini, berbagai usaha dilakukan untuk mengurangi ketergantungan terhadap minyak, salah satunya memanfaatkan sumber energi alternatif yang ada. Terdapat banyak sumber energi alternatif di Indonesia, salah satunya yaitu bahan-bahan limbah 
organik yang dapat dijadikan bahan bakar alternatif, contohnya pembuatan briket.

Namun dibalik ancaman serius di atas, ada peluang bagi energi-energi alternatif, khususnya bagi energi yang dapat diperbaharui (renewablde energy), satu diantaranya adalah biomassa ataupun bahan-bahan limbah organik. Bidomassa ataupun bahan-bahan limbah organik ini dapat diolah dan dijadikan sebagai bahan bakar alternatif, contohnya dengan pembuatan briket. Selama ini, pembuatan briket kebanyakan hanya terbuat dari batubara saja. Maka, peneliti mencoba pemdbuatan briket dari eceng gondok, serbuk gergaji dan kulit kakao.

Pesatnya pertumbuhan eceng gondok mengakibatkan berbagai kesulitan seperti terganggunya transportasi, penyempitan sungai, dan masalah lain karena penyebarannya yang menutupi permukaan sungai/perairan. Begitupun dengan limbah serbuk gergaji dan kulit kakao terus menumpuk dan menjadi limbah biomassa, maka dapat dilakukan suatu pemanfaatan alternatif terhadap limbahlimbah tersebut dengan jalan pembuatan briket arang. Kandungan selulosa dan senyawa organik pada enceng gondok berpotensi memberikan nilai kalor yang cukup baik. Dengan demikian briket arang dari enceng gondok ini dapat dimanfaatkan sebagai bahan bakar alternatif, begitupun dengan limbah serbuk gergaji dan kulit kakao

Berdasarkan penelitian dengan melakukan perbandingan bahan antara serbuk gergaji dan kulit pisang dengan perbandingan (90:10), perbandingan tersebut menghasilkan nilai kalor dan kadar air briket terbaik yaitu berturut turut $(6955,144 \mathrm{kal} / \mathrm{gr}$ dan 2,06. Berdasarkan pemaparan diatas, peneliti mamanfaatkan tanaman Eceng Gondok (Eichornia cressipes), limbah serbuk gergaji dan kulit kakao untuk penentuan nilai kalor melalui proses pembriketan dengan perbandingan $(90: 10,75: 25$ dan $50: 50)$.

\section{Tujuan}

Tujuan yang dapat dicapai dari penelitian ini adalah sebagai berikut:

1. Untuk mengetahui pengaruh parameter yang digunakan terhadap kualitas briket yang dihasilkan.

2. Untuk mengetahui nilai kalor terbaik dan terendah yang didapatkan dari pencampuran variasi bahan dalam pembuatan briket.

\section{METODE PENELITIAN}

Alat

Alat-alat yang digunakan dalam penelitian ini yaitu alat-alat gelas, tabung pembakar, timbangan, alat pengopres, tanur, oven dan timbangan. 


\section{Bahan}

Bahan - bahan yang digunakan dalam penelitian ini yaitu eceng gondok, kulit kakao, serbuk gergaji, getah pinus, aquadest $\left(\mathrm{H}_{2} \mathrm{O}\right)$ dan aluminium foil.

\section{Prosedur Penelitian}

\section{Proses Karbonisasi Eceng Gondok, Serbuk Gergaji dan Kulit Kakao}

Melakukan pengambilan eceng gondok, serbuk gergaji dan kulit kakao. Dikeringkan dibawah sinar matahari. Menyiapkan alat dan bahan. Selanjutnya serbuk gergaji dimasukkan ke dalam tabung pembakaran kemudian tabung ditutup dan dikunci lalu menyiapkan kayu kering dan diletakkan dibawah tabung pembakaran. Menunggu sekitar 20 menit sampai semua bahan baku menjadi arang. Arang dikeluarkan dan dipisahkan dengan yang menjadi abu. Kemudian arang yang telah dingin kemudian di giling hingga halus dan siap dicetak menjadi briket.

\section{Proses Pembuatan Briket}

Arang serbuk gergaji, kulit kakao dan arang eceng gondok yang telah disaring kemudian dibuat briket pada beberapa komposisi bahan baku setelah terlebih dahulu dicampur dengan perekat getah pinus sebanyak $60 \%$. Pembuatan briket ini dibedakan menjadi 9 kombinasi bahan baku yaitu perbandingan serbuk gergaji : eceng gondok, serbuk gergaji : kulit kakao dan kulit kakao : eceng gondok dengan masing - masing perbandingan (90:10, 75 : 25 dan 50 : 50). Masing-masing komposisi bahan baku yang telah dibuat selanjutnya dimasukkan ke dalam alat cetak kemudian ditekan. Kemudian mengeluarkan hasil cetakan briket. Kemudian melakukan proses pengeringan sekitar $1-2$ hari dibawah sinar matahari.

\section{Uji Kimia}

\section{Kadar air (Moisture)}

Prosedur pengukuran kadar air (moisture) yaitu cawan porselin diovenkan pada suhu $105^{\circ} \mathrm{C}$ (1 jam). Mendinginkan dalam eksikator ( $\left.1 \frac{1}{2} \mathrm{jam}\right)$,di timbang (A gram). Kedalam cawan porselin ditimbang lebih kurang 1 gram contoh (cawan porselin + contoh $=\mathrm{B}$ gram). Memasukkan kedalam oven pada suhu $105{ }^{\circ} \mathrm{C}$ minimal selama 2 jam, mendinginkan kedalam eksikator selama 1 jam. Selanjutnya ditimbang dan memanaskan kedalam oven dengan suhu yang sama dan ditimbang kembali hingga menghasilkan selisih massa dibawa 0,0005 gram (C). 


\section{Kadar abu (Ash)}

Prosedur pengukuran kadar Abu (Ash) yaitu cawan porselin diovenkan pada suhu $105{ }^{\circ} \mathrm{C}(1 \mathrm{jam})$. Mendinginkan dalam eksikator ( $\left.1 / 2 \mathrm{jam}\right)$ kemudian di timbang (A gram). Kedalam cawan porselin ditimbang lebih kurang 1 gram contoh (B gram). Mentanurkan pada suhu $650{ }^{\circ} \mathrm{C}(2 \mathrm{jam})$, dinginkan dalam desikator (1 jam) kemudian ditimbang dan panaskan kembali lalu menimbang hingga selisih massa 0,0005 gram (C).

\section{Volatile Matter (VM)}

Prosedur pengukuran volatile matter (VM) yaitu sebagai cawan porselin diovenkan pada suhu $105^{\circ} \mathrm{C}(1 \mathrm{jam})$. Mendinginkan dalam eksikator ( $\left.1 / 2 \mathrm{jam}\right)$ kemudian ditimbang (A gram). Kedalam cawan porselin ditimbang lebih kurang 1 gram contoh (B gram). Mentanurkan pada suhu suhu $900{ }^{\circ} \mathrm{C}$ (7 menit), mendinginkan dalam desikator (45 jam) kemudian ditimbang hingga selisih massa dibawa 0,0005 gram ( $\mathrm{C}$ gram).

\section{Fixed Carbon (FC)}

Fixed Carbon dihitung dari $100 \%$ dikurangi dengan kadar air lembab (moisture) dikurangi kadar abu, dikurangi kadar zat terbang (volatile matters).

\section{Nilai kalor}

Prosedur pengukuran nilai kalor (HHV) yaitu Menimbang 1 gram sampel yang sudah dipisahkan kedalam cawan besi. Menyiapkan rangkaian bom kalorimeter, menghubungkan dengan kawat platina dan menyentuhkan dengan sampel. Memasukkan air sebanyak $1 \mathrm{ml}$ ke dalam bejana bom kalorimeter, lalu memasukkan rangkaian bom kalorimeter kedalam bejana. Menutup rapat lalu isi dengan gas pada tekanan 130 ATM. Mengisi ember bom kalorimeter dengan 2 liter air dan memasukkan kedalam jaket bom kalorimeter. Memasukkan bejana bom kedalam ember kemudian ditutup. Menjalankam mesin dan melihat suhu awal. Setelah 5 menit, menemkan tombol pembakaran dan biarkan selama 7 menit. Lihat suhu akhir dan matikan mesin.

\section{Uji Fisika}

\section{Kerapatan $(\rho)$}

Pengujian ini dilakukan dengan mendeterminasi berapa rapat massa briket melalui perbandingan antara massa briket dengan besarnya dimensi volumetrik briket. Langkah pengujian kerapatan yaitu Menyiapkan peralatan 
yang digunakan termasuk benda uji, menimbang berat briket, mengukur volume briket (volume silinder).

\section{Kuat tekan}

Menyalakan mesin, meletakkan briket pada tumpuannya. Melakukan penyetelan jarum hitam dan merah pada manometer keposisi 0 (nol), pengujian dimulai dengan mendorong handle penggerak motor kedepan. Memperhatikan dan jarum petunjuk pada manometer selama penekanan. Menarik kembali handle penggerak motor keposisi semula. Mencatat penunjukkan temperatur briket (untuk memperoleh temperatur maksimum briket).

\section{HASIL DAN PEMBAHASAN}

Nilai kadar air, kadar abu, kadar zat terbang, nilai karbon tetap, kerapatan, kuat tekan dan nilai kalor dapat dilihat pada grafik dibawah ini

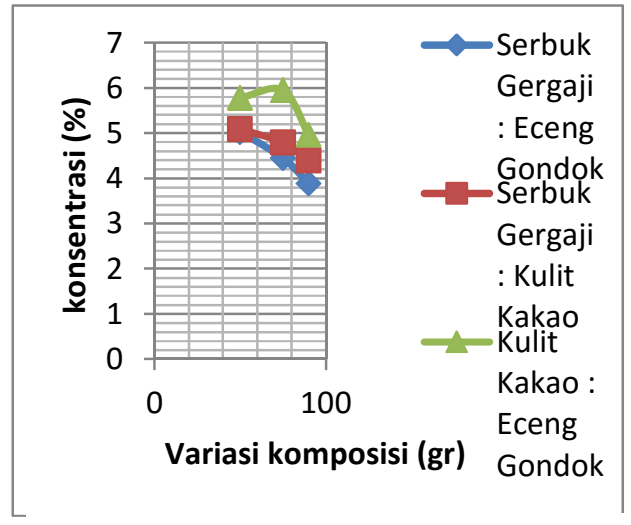

Gambar 1.Kadar Air Perbandingan Serbuk Gergaji, Kulit Kakao dan Eceng Gondok

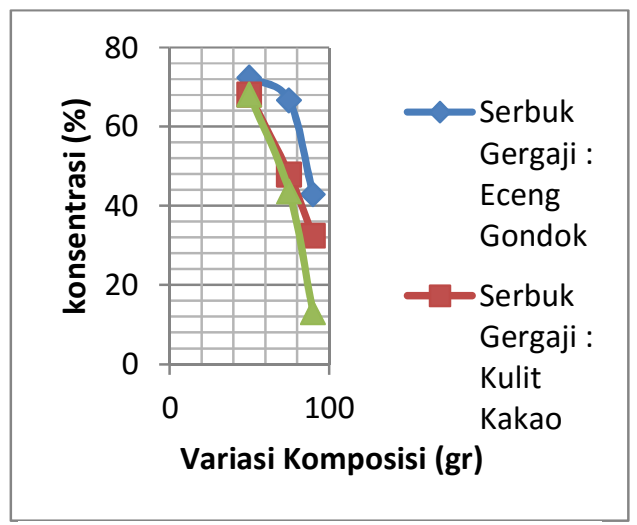

Gambar 3.Kadar zat terbang perbandingan serbuk gergaji, kulit kakao dan eceng gondok

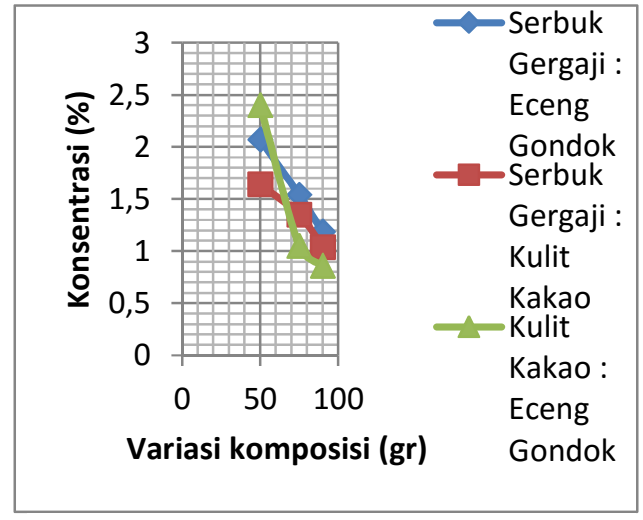

Gambar 2.Kadar Abu Perbandingan Serbuk Gergaji, Kulit Kakao dan Eceng Gondok

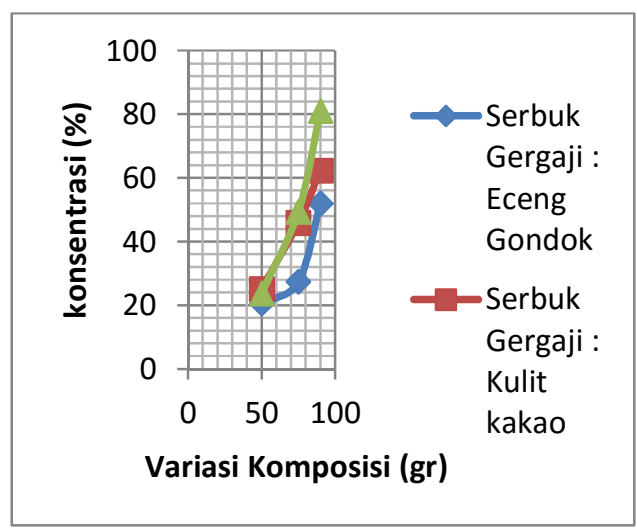

Gambar 4.Kadar karbon tetap perbandingan serbuk gergaji, kulit kakao dan eceng gondok 


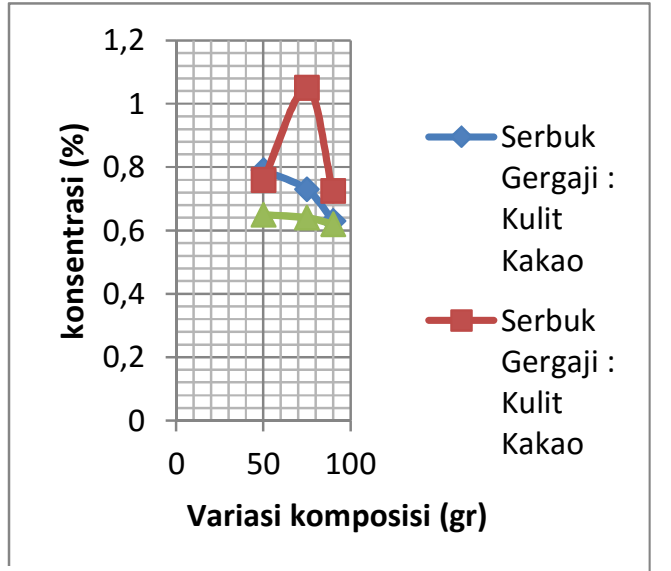

Gambar 5.Nilai kerapatan perbandingan serbuk gergaji, kulit kakao dan eceng gondok

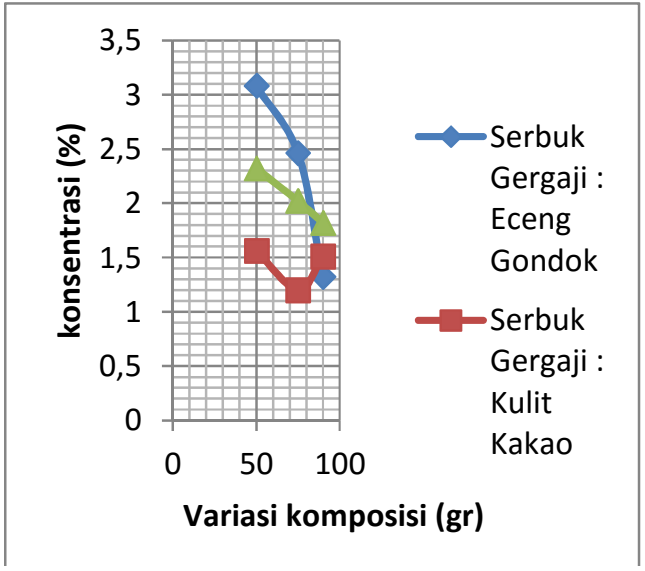

Gambar 6.Nilai kuat tekan perbandingan serbuk gergaji, kulit kakao dan eceng gondok

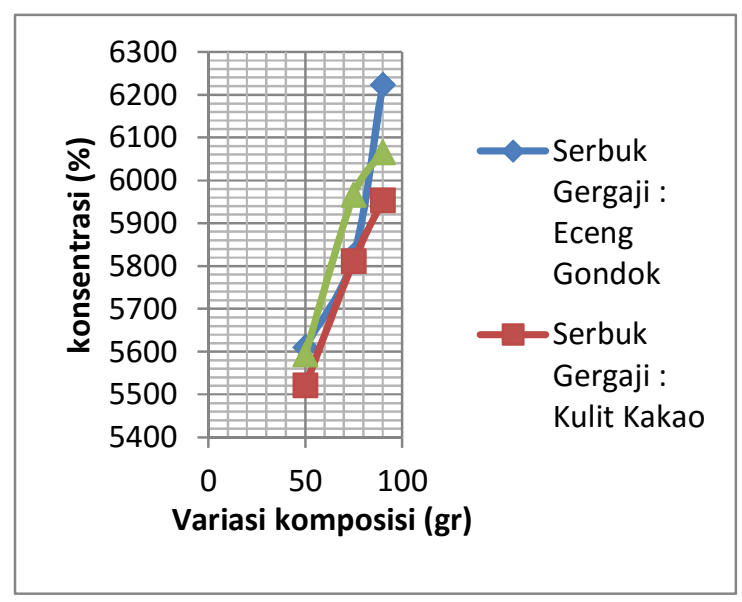

Gambar 7.Nilai kalor perbandingan serbuk gergaji, kulit kakao dan eceng gondok

Berdasarkan hasil penelitian didapatkan nilai kadar air terbaik terdapat pada perbandingan serbuk gergaji : eceng gondok $(90: 10)$ yaitu $3,89 \%$. Nilai kadar abu terbaik terdapat pada perbandingan kulit kakao : eceng gondok (90 : 10) yaitu $0,66 \%$. Nilai kadar zat terbang terbaik terdapat pada perbandingan serbuk gergaji : eceng gondok (90:10) yaitu 13,1\%. Kadar karbon tetap terbaik pada perbandingan kulit kakao : eceng gondok ( $90: 10)$ yaitu $81,08 \%$. Nilai kalor tertinggi didapatkan pada perbandingan serbuk gergaji : eceng 
gondok (90 : 10) yaitu 6223,20 kal/gr. Sedangkan nilai kerapatan dan kuat tekan terbaik terdapat pada perbandingan serbuk gergaji : eceng gondok (50 : 50) yaitu $0,79 \mathrm{gr} / \mathrm{cm}^{3}$ dan $3,08 \mathrm{gr} / \mathrm{cm}^{3}$.

\section{Pengaruh Variasi Bahan Terhadap Nilai Kadar Air dan Kadar Abu yang Dihasilkan}

Penambahan bahan serbuk gergaji dan kulit kakao akan menghasilkan kadar air yang kurang karena bahan tersebut cenderung memiliki kandungan air yang kurang, maka perbandingannya lebih tinggi dibandingkan eceng gondok yang memiliki kandungan air lebih tinggi, sehingga semakin sedikit perbandingan eceng gondok yang dipakai maka kadar air yang didapat kurang. Semakin banyak jumlah serbuk gergaji dan kulit kakao yang dimasukkan dalam komposisi briket maka akan menurunkan kadar abu dan begitupun sebaliknya, dimana kandungan abu dari serbuk gergaji yaitu 0,66 \% sedangkan kandungan abu pada kulit kakao yaitu 1,06\%.

\section{Pengaruh Penambahan Variasi Bahan terhadap Kadar Zat Terbang dan Karbon Tetap yang Dihasilkan}

Penambahan serbuk gergaji, kulit kakao dan eceng gondok sebanyak 90\% akan meningkatkan kadar karbon tetap. Hal ini dipengaruhi oleh proses karbonisasi perbandingan tersebut sangat baik, dimana suhu pembakaran yang tinggi akan meningkatkan kadar karbon dalam arang serbuk gergaji dan kulit kakao karena banyak material yang terbakar sehingga karbon yang dihasilkan semakin banyak. Penambahan serbuk gergaji dan kulit kakao akan menurunkan kadar zat terbang pada briket disebabkan karena kandungan minyak pada Serbuk Gergaji dan kulit kakao kurang sehingga kadar zat terbang yang dihasilkan menurun.

\section{Pengaruh Penambahan Variasi Bahan terhadap Nilai Kerapatan dan Kuat Tekan yang Dihasilkan}

Penambahan seruk gergaji dan kulit kakao (50:50) \% akan meningkatkan nilai kerapatan disebabkan karena penambahan eceng gondok dan kulit kakao yang banyak menyebabkan bidang permukaan antar serbuk menjadi luas sehingga ikatan antar serbuk menjadi kompak dan kuat. Ukuran eceng gondok dan kulit kakao lebih halus dan seragam sehingga ikatan antar partikel arang lebih maksimal dan menyebabkan kerapatan yang dihasilkan lebih tinggi. Begitupun dengan penambahan serbuk gergaji : eceng gondok (50:50)\% akan meningkatkan nilai kuat tekan disebabkan karena kulit kakao dan eceng gondok memiliki partikel arang halus yang menyebabkan nilai 
kerapatannya tinggi sehingga berpengaruh terhadap kuat tekan bahan tersebut, juga dipengaruhi oleh proporsi campuran bahannya seimbang.

\section{Pengaruh Nilai Kadar Air, Kadar Abu, Kadar Zat Terbang, Kadar Karbon} Tetap, Nilai Kerapatan, Kuat Tekan Terhadap Nilai Kalor yang Dihasilkan

Peningkatan nilai kalor dipengaruhi oleh kurangnya kadar air, kadar abu, kadar zat terbang dan meningkatnya kuat tekan serta kerapatannya. Nilai kalor terbaik terdapat pada perbandingan serbuk gergaji 90 : eceng gondok 10 yaitu 6223,20 kal/gr dan perbandingan kulit kakao 90 : eceng gondok 10 yaitu $6066,09 \mathrm{kal} / \mathrm{gr}$. Sedangkan nilai kalor terendah terdapat pada perbandingan serbuk gergaji 50 : eceng gondok 50 yaitu 5608,86, hal ini disebabkan karena kadar air, kadar abu dan zat terbangnya sangat tinggi, juga sangat kurang kuat tekan dan kerapatannya.

\section{PENUTUP}

\section{Kesimpulan}

Berdasarkan dari hasil pengamatan dan pembahasan, kesimpulan dari hasil penelitian yang telah dilakukan yaitu:

a. Parameter yang diujikan berpengaruh terhadap kualitas briket yang dihasilkan dimana briket yang memiliki kuat tekan, kerapatan, kadar air, kadar abu, kadar zat terbang, karbon tetap terbaik menghasilkan nilai kalor terbaik.

b. Nilai kalor terbaik dihasikan pada perbandingan serbuk gergaji 90 : eceng gondok 10 yaitu 6223,20 kal/gr, serbuk gergaji 90 : kulit kakao 10 yaitu $5953,09 \mathrm{kal} / \mathrm{gr}$ dan perbandingan kulit kakao 90 : eceng gondok 10 yaitu $6066,09 \mathrm{kal} / \mathrm{gr}$. Sedangkan nilai kalor terendah didapatkan pada perbandingan serbuk gergaji 50 : kulit kakao 50 yaitu 5521,17 kal/gr dan perbandingan kulit 50 : eceng gondok 50 yaitu $5593,16 \mathrm{kal} / \mathrm{gr}$

\section{Saran}

Saran dari penelitian ini yaitu sebaiknya pada penelitian selanjutnya menggunakan mesin pembuatan briket yang lebih canggih, agar briket yang dihasilkan memiliki kualitas yang baik.

\section{DAFTAR PUSTAKA}

Aristyanto, Eko., 2004, Pembuatan Biobriket dari Campuran Limbah Kulit Pisang dan Serbuk Gergaji Menggunakan Perekat Tetes Tebu,Jurnal Teknik Kimia, 12(3). 
Budi, Esmar., 2011, Pemanfaatan Briket Arang Tempurung Kelapa Sebagai Bahan Bakar Pengganti,Jurnal Fisika, 12(2).

Departemen Agama, 1989, Al Quran dan terjemahannya, Semarang: CV Toha Putra.

Dogra, SK., 2009,Kimia Fisik dan Soal-Soal, Jakarta: UI - Press.

Fachri, Rasyidi, A., 2010, Mencari Suhu Optimal Proses Karbonisasi dan Pengaruh Campuran Batubara Terhadap Kualitas Briket Eceng Gondok,Jurnal Teknik Kimia,17(2).

Gandhi, Aquino., 2010, Pengaruh Variasi Jumlah Campuran Perekat Terhadap Karakteristik Briket Arang Tongkol Jagung,Jurnal Teknik Kimia,8(1).

Himawanto, Dwi Aries, 2013,Penentuan Energi Aktivasi Pembakaran Briket Char Sampah Kota Dengan Menggunakan Metoda Termogravimetry dan Isotermal Furnace, Jurnal Sains. 15(3).

Holman, J.P., 1995,Kalor Perpindahan, Jakarta: Erlangga.

Irfanti, Eka., 2013, Karakterisasi Briket Bioarang Limbah Kulit Pisang Uli (Musa Paradisiaca) dengan Perekat Tepung Tapioka,Jurnal Teknik Kimia, 14(2).

Martinis, Munas., 2012, Pembuatan Biobriket dari Limbah Cangkang Kakao,Jurnal Teknik Kimia, 20(3).

Mirnawati, 2012, Pengaruh Perekat Getah Pimus Terhadap Peningkatan Nilai Kalor dari Tempurung Kelapa dan Sekam Padi,Jurnal Kimia, 18(5).

Nasirotunnisa, 2010, Analisis Nilai Kalor Bahan Bakar Biomassa yang DapatDimanfaatkan Menggunakan Kompor Biomassa,Skripsi, Jakarta: Universitas Indonesia.

Putra, Resha Widya, 2012, Peningkatan Nilai Kalor Biobriket Campuran Kulit Mete dan Dominani Sekam Padi Dengan Metode Pirolisa,Jurnal Teknik Mesin, 19(8).

Rosyidi, Jalal Soelaiman, 2013,Perbandingan Karakteristik antara Briket Briket Berbahan Dasar Sekam Padi sebagai Energi Terbarukan, Jurnal Fisika Fisika, 15(4).

Sari, Noor Mirad, 2009, Analisis Biaya dan Waktu Pembuatan Briket Arang Berdasarkan Bentuk Dari Kayu Bakau (Rhizophora mucronata Lamck) dan Rambai (Sonneratia acidalin), Jurnal Teknik Kimia,20(26).

Sulistyanto, Amin., 2006,Karakteristik Pembakaran Biobriket Campuran Batubara dan Sabut Kelapa, Jurnal Teknik, 2(7).

Teguh Husada, Ibnu, 2010,Arang Briket Tongkol Jagung sebagai energi alternatif,Jurnal Teknik Kimia, 2(7). 